\title{
( Materiality of Disclosure of Non-financial aße Sustainability Information and Company Financial Research house Performance: Evidence from Australian Listed Companies
}

\section{Ashraf Al Mamun}

Associate Professor and Director (Research, Development \& Consultancy), Bangladesh Institute of Bank Management (BIBM), Mirpur-2, Dhaka-1216, BANGLADESH

E-mail for correspondence: mamun@bibm.org.bd

\begin{abstract}
The broad objective of this paper is to examine the relationships between the disclosure of non-financial material sustainability information and the financial performance of listed Australian companies in the materials sector. Using firm-level fixed-effects analysis for all companies, the findings show a mixed relationship (no relationship or statistically significant negative relationship) between lagged aggregate non-financial material sustainability disclosure and financial performance of Australian listed companies in the materials sector. This study contributes to the existing literature on disclosure of nonfinancial sustainability information by adding insights into the materiality concept of non-financial sustainability disclosure in the Australian context. The evidence from the current study is expected to provide valuable information for the companies' stakeholders in Australia who use both financial and non-financial information for formulating business and regulatory policies and for decisions regarding the persistent expansion of sustainability reporting requirements.
\end{abstract}

Keywords: Non-financial disclosure, material sustainability information, sustainability reporting, GRI guidelines, materiality, financial performance, Australia

\section{INTRODUCTION}

The materiality of disclosure is a relatively new concept in sustainability reporting, which focuses on the usefulness of the information being reported (Unerman and Zappepettini, 2014; Edgley et al., 2015). It is related to recognizing those economic, environmental, and social issues that matter most to a company and its stakeholders. Materiality concept helps to distinguish between important information and insignificant immaterial information. Materiality reporting on sustainability issues plays an important role in enhancing the long-term value maximization of the companies by focusing on the most relevant issues (Porter and Kramer, 2006; Kyte, 2007) and avoids over-reporting and greenwashing (Font et al., 2016). It is the view by $25 \%$ of respondents of a worldwide survey conducted by KPMG and SustainAbility (2008) that material issues are absent from the sustainability reports and also the material issues are not treated with enough detail. Therefore, it is relevant to explore the context of materiality while considering the disclosure of nonfinancial sustainability information of companies.
Although there exists a large number of empirical studies on corporate social responsibility (CSR) and environmental, social, and governance (ESG) which focus on how such information impacts company performance (Moskowitz, 1972; Vance, 1975; Sturdivant and Ginter, 1977; Spicer 1978a; Spicer 1978b; Abbott and Monsen, 1979; Chen and Metcalf, 1980; Cochran and Wood, 1984; Ullmann,1985; Griffin and Mahon, 1997; Waddock and Graves, 1997; McWilliams and Siegel, 2000; Lin et al., 2009; Flammer, 2013; Flammer, 2015; Lu and Taylor, 2015; Choi and Moon, 2016; Kang et al., 2016), the studies have mainly been conducted on CSR reporting, analyzing disclosures that contained CSR issues and relationship between CSR issues and company performance. What has not been investigated is whether this information is material.

Research on disclosure of non-financial material sustainability information related to sustainability issues by companies in Australia and abroad is at a nascent stage, and thus, this is an emerging and growing field of research. The few studies that have been conducted so far in this area (Khan et al., 2016; Amel-Zadeh, 2016; Lins et al., 2017; Jones 
et al., 2016; Eccles et al., 2012) are primarily in the US context. Studies related to disclosure of companies' nonfinancial material sustainability information in the Australian context (Font et al., 2016; Ong et al., 2016; and Ong, 2016) are very limited and largely unexplored.

In the Australian context, although Font et al., (2016) and Ong et al., (2016) analyses the materiality of disclosure of nonfinancial issues, however, the studies do not examine the relationship between companies' disclosure of non-financial material sustainability information and their performance. The other study, Ong (2016), using Global Reporting Initiative (GRI) G3.1 guideline, finds significant positive correlations between the disclosure of sustainability information and company characteristics, and that companies in the resources industry place more emphasis on economic aspects than environmental and social aspects when disclosing such information. The limitation of Ong's study is that it uses only one year (2012) data for the top 50 ASX listed companies in the Australian resources industry and does not include any sector-specific analysis. Therefore, from Ong's study, it is not possible to understand the sector-specific relationship between non-financial material sustainability information and company financial performance.

The present study used the Global Reporting Initiative (GRI) G4 guidelines to disclosure of non-financial material sustainability information, the latest version available for GRI guidelines. Thus, this study is different from the other studies mentioned above in the Australian context. Based on the limitations of the mentioned studies discussed above on disclosure of non-financial material sustainability information in the Australian context, an important gap exists in this field. Although Khan et al., (2016) uses the materiality aspects of non-financial sustainability disclosure, it is based on SASB guidelines of materiality and the USA companies' context, and not based on the GRI guideline and Australian companies' context. Moreover, considering the Australian context, the present study uses a stronger analytic approach that fully exploits the longitudinal nature of the data compared to studies mentioned above (Font et al., 2016; Ong et al., 2016; and Ong, 2016).

Using the GRI G4 guidelines as a benchmark, the present study provides the landscape of disclosure of non-financial material sustainability information among Australian companies in the materials sector. The current study is the only study so far, which empirically examines the relationships between disclosure of non-financial material sustainability information and the financial performance of Australian listed companies in the materials sector.

On this background, the objective of the present study, which comprises 100 companies of the materials sector (the largest sector in the ASX) listed in the Australian Securities Exchange (ASX), is to investigate the relationships between disclosure of non-financial material sustainability information and the financial performance based on GRI G4 guidelines on economic, environmental and social performance aspects.
This study uses the GRI G4 definition of materiality and guidelines for disclosure of non-financial material sustainability information because it is more comprehensive and widely used by companies all over the world (KPMG, 2015; Brown et al., 2009; Frost et al., 2005). While et al., (2006) note that, "GRI claims to provide the basis of worldwide standardized, comparable, reporting on the sustainability of (particularly business) organizations" (p. 268). The most recent version of the GRI guidelines (introduced in May 2013), the GRI G4 guidelines, underscore the meaning of materiality in sustainability reporting and materiality is placed at the core of these guidelines. These guidelines are not merely a data-gathering exercise; rather they focus only on the most important aspects (material aspects) of sustainability reporting. According to the GRI G4 Sustainability Reporting Guidelines Implementation Manual, "Material aspects are those that reflect the organization's significant economic, environmental, and social impacts; or that substantively influence the assessments and decisions of stakeholders. To determine if an aspect is material, qualitative analysis, quantitative assessment, and discussion are needed" (GRI, 2013b, p.244).

Although the GRI sustainability reporting guideline has increased usage by companies worldwide, it has a few limitations. One such limitation is that it mainly focuses on the number of indicators and does not focus on the amount of information disclosed. According to Brown et al., (2009) "GRI reports do not give an adequate picture of progress toward sustainability" (p. 196). Therefore, the GRI sustainability framework may not show the real sustainability performance of the companies. Despite the mentioned limitation of the GRI framework, using GRI G4 guidelines, the present study examines the relationship between disclosure of non-financial material sustainability information and their financial performance by Australian listed companies in the materials sector.

This paper proceeds with the literature review in Section 2, followed by the methodology in Section 3. Section 4 presents the study findings and discussion. Section 5 presents the study contributions and implications. Section 6 discusses the study limitation followed by the future research scope in Section 7. Section 8 concludes the discussion.

\section{LITERATURE REVIEW}

There is a scarcity of literature on the disclosure of nonfinancial material sustainability information and company financial performance. Few studies highlight the issue of non-financial disclosing of material sustainability information. There is a need for sector-specific materiality disclosure standards and key performance indicators (KPIs) for reporting on companies' sustainability information, which would significantly improve the ability of companies to report on their ESG performances (Eccles et al., 2012). Although the study focuses on the necessity of the disclosure of material sustainability information, it 
does not analyze the relationship between companies' disclosure of non-financial material sustainability information and their financial performance.

Using the SASB materiality guidelines by sectors Khan et al., (2016) examined the material and immaterial nonfinancial disclosures of sustainability issues for more than 2,300 USA companies in six different sectors. The researchers claim that the study was the first of its kind to analyze the relationship between companies' disclosure of non-financial material sustainability information and their performance. They find that the stock value of companies with high ratings on material ESG issues in their respective sectors considerably outperformed companies with a low rating on material ESG issues. The stock value does not have any difference for those firms with a high rating on immaterial ESG issues. Thus, the disclosure of material ESG issues can be value-enhancing for shareholders, while disclosure of non-material ESG issues has little value implications. Although the study used the materiality aspects of non-financial sustainability disclosure, it is based on SASB guidelines of materiality for the USA-based companies and not based on the GRI guidelines.

Disclosure of companies' non-financial material sustainability information has recently been gaining importance in the UK. After examining the top ten leading UK retail companies, Jones et al., (2016) find that the companies embrace reporting of material sustainability information, however, there is a lack of a unified approach adopted to measure the materiality of disclosed information. Amel-Zadeh (2016) explains the theoretical foundations and empirical evidence of the materiality of non-financial sustainability disclosure. Both the studies do not examine the relationship between the relationship between companies' disclosure of non-financial material sustainability information and their financial performance.

As the literature in the field of disclosure of non-financial material sustainability information and company performance is very limited, the scope for exploring this field is immense. It is, therefore, relevant to analyze the relationship between companies' disclosure of nonfinancial material sustainability information and their financial performance in the Australian context. Disclosure of non-financial sustainability information is not mandatory in Australia. In the mid-2000s, after reviewing company legislature, the Australian Government made sustainability reporting voluntary for businesses (Higgins et al., 2015). For certain industries, (e.g., mining, metal, energy, utility, manufacturing, etc.) disclosure of some environmental issues is mandatory.

Sustainability reporting and disclosure is slowly gaining momentum in Australia (Figure 1). The figure shows the trend of sustainability reporting based on GRI, GRIreferenced and non-GRI categories of Australian companies from 1999 to 2016 . It is evident that the number of companies reporting on sustainability information has been increasing gradually since 1999 .
Figure 1: Trend of sustainability reporting of Australian companies (GRI, GRI-referenced and non-GRI) from 1999 to 2016

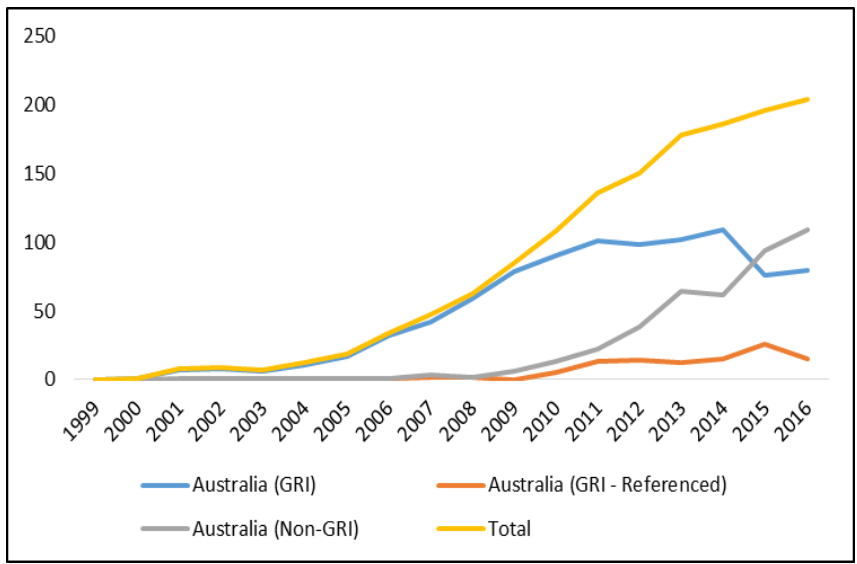

Source: Compiled from the complete version of the GRI Reports List (2017), Global Reporting Initiative Database. Available

at:

https://www.globalreporting.org/services/Analysis/Repor ts List/Pages/default.aspx

Australian companies are disclosing sustainability information in their annual reports, corporate governance statements, CSR/sustainability reports/reviews and workplace gender equality agency (WGEA) report. Based on the company websites, it is found that, some companies disclose their sustainability information in a single annual report, some publish standalone sustainability reports, while others use a mixed approach by disclosing sustainability reports in annual reports as well as other reports mentioned above.

Studies related to disclosure of companies' non-financial material sustainability information in the Australian context are very limited. There are few studies (Font et al., 2016; Ong et al., 2016; Ong, 2016) that examine the context of companies' material sustainability information disclosure.

Font et al., (2016) analyzed the materiality of disclosure of non-financial issues for the cruise industry in Australia following the non-financial disclosure standard as mentioned in the GRI guidelines. It finds that the cruise companies over-report immaterial issues and under-report material issues. However, the relationship between companies' disclosure of non-financial material sustainability information and their financial performance was not examined.

Based on the GRI G3.1 guideline and using listed ASX 50 companies for 2012, Ong et al., (2016) find that there is a lack of a standardized reporting framework while reporting companies' sustainability information in Australia and Australian companies in the resources industry are producing minimal sustainability information with a great degree of variation. It also finds that companies in the resources industry place more emphasis on economic aspects than the environmental and social 
aspects when disclosing such information. Again, the relationship between disclosure of non-financial sustainability information and companies' financial performance was not investigated.

Using the GRI G3.1, Ong (2016) examined the relationship between companies' disclosure of non-financial material sustainability information and their financial performance along with other company characteristics (company size, proportion of independent directors, multiple directorships and women directors on the board) in the Australian resources industry (metals and mining sector, and energy and utilities sector). The study uses ASX 50 listed companies in the resources industry on the basis of market capitalization and analyses their performance for only one year, 2012. It finds significant positive correlation between disclosure of sustainability information and company characteristics (company size, financial performance, the proportion of proportion of independent directors, and multiple directorships and women directors on the board). It also finds that companies in the resources industry place more emphasis on economic aspects than environmental and social aspects when disclosing such information. Although the study covers economic, social and environmental disclosures, it only uses one-year (2012) of company data for the top 50 ASX listed companies in the Australian resources industry. Ong (2016) recommends that the use of panel data may be suitable to better examine the relationship between companies' disclosure of nonfinancial material sustainability information and their financial performance.

The status of disclosure of non-financial material sustainability information in Australia is in a nascent stage. There is ample scope for Australian companies to focus more on non-financial material sustainability disclosure issues. This may lead to capturing the benefits of disclosing the non-financial material sustainability information in the long run-in terms of financial as well as market return.

\section{MetHOdOLOGY}

\section{Study Sample}

Based on the DatAnalysis Premium database, we randomly selected 100 companies (15.7\% of the population of 636$)$ in the "materials sector" of the Australian Stock Exchange (ASX) listed companies as the listed companies are larger in size (Yongvanich and Guthrie, 2005), and have noteworthy impact on the economy as producers and employers (Andrikopoulos and Kriklani, 2013). This study relies on the DatAnalysis Premium database for sample selection as the database provides a variety of financial and other information necessary for the study. Even though the total number of ASX listed companies in the materials sector is 677, the DatAnalysis Premium database included data on 636 of these companies when data were extracted in May 2017 (for data period from 2014 to 2016). Thus, 41 companies (6\%) of the total 677 ASX listed companies in the materials sector are excluded from the analysis. From the 636 companies, 100 companies have been selected randomly using the random number function in MS-Excel. Consequently, the sampled 100 companies represent the sub-population of 636 ASX listed companies in the material sector. The summary of the sample selection process is as follows:

- Step 1: Total number of ASX listed companies in $\underline{\mathbf{6 7 7}}$ the Materials sector

- Step 2: Data available in DatAnalysis Premium 636

- Step 3: Number of randomly selected sample 100 companies (from 636 companies)

Among the 11 ASX industry sectors, this study chooses the materials sector because this sector constitutes the highest number of companies in any given sector (677), constituting $30.9 \%$ of all listed companies in the ASX $(2,193)$ based on the Global Industry Classification Standard (GICS) which was accessed from their websites. Moreover, some of the subsectors of the materials sector (mining, wood and paper, non-metallic mineral products and metal products) together have highest contribution to the Australian GDP (measured by industry gross value added) among the twenty sectors reported for the Australian GDP estimates (Australian Bureau of Statistics 2015, p.36). The contribution of these sub-sectors of the materials sector to the Australian GDP was about $10 \%$ in $2013-14$ and increased to $10.4 \%$ and $10.5 \%$ in 2014-2015 and 2015-2016, respectively. If the data for all sub-sectors of the materials sector were available, then the contribution of this sector to the Australian GDP is likely to be higher. The study focuses on the materials sector considering the substantial contribution of the sector to the Australian economy. The Australian Government also puts emphasis on industry-specific sustainability reporting (Dong and Burritt, 2010). Sector-specific reporting may enhance the comparability among the companies included in the specific sector.

A sample size of 100 ASX companies (a sample of $15.7 \%$ of the population of 636 companies) would be sufficiently large for statistical analysis based on the central limit theorem, which suggests that the analysis will be able to make statistical inferences based on the standard normal distribution (Bowerman et al., 2017, pp 334-335). With limited time and resources available for this research, a sample size of 100 struck a balance between what was essential for drawing valid statistical inference, and the resources necessary to collect all the relevant data. As the data on disclosure of material sustainability information for the present study were manually collected by the researchers through content analysis of various reports published by the companies, it was not possible to extend the sample size beyond 100 companies due to resource and time constraints.

\section{Data sources, data collection and period for analysis}

This study collects secondary data from the websites of the sampled companies, which include annual reports, sustainability reports/reviews, workplace gender equality agency (WGEA) reports, environmental reports/reviews 
and other relevant publications. Information about companies' financial performance is accessed from DatAnalysis Premium, a database that provides ASX listed companies' financial data. Data on general and sectorspecific economic conditions are collected from published reports by the Australian Bureau of Statistics. The study covers three-year period, from 2014 to 2016. As the GRI G4 was introduced in May 2013, the analysis period covers sustainability information reporting practices after the introduction of GRI G4 guidelines. The study analyses company-wise disclosures of GRI G4 sustainability indicators on aggregate as well as economic, environmental and social aspects for 2014 and 2015, and measure the financial performance of those companies for 2015 and 2016.

\section{Content analysis}

This study applied content analysis to collect data about sustainability information from different annual reports and sustainability reports of the Australian listed companies in the materials sector. This study manually collected the information from the reports and mapped with the GRI G4 guidelines to check whether disclosure is consistent with each GRI G4 performance indicator. Next, the scoring index for disclosure of material sustainability information is developed. Khan et al., (2016) use handmapping while matching SASB materiality issues with Kinder, Lydenberg, Domini (KLD) sustainability issues.
Content analysis is used in numerous studies in sustainability reporting to analyze the content of published annual reports and sustainability reports of companies (Abbott and Monsen, 1979; Cochran and Wood, 1984; Guthrie and Parker, 1990; Tilt, 2001; Frost et al., 2005; Guthrie and Abeysekera, 2006; Clarkson et al., 2008; Dong and Burritt, 2010; Lu et al., 2014; Richards et al., 2015).

Developing a scoring index for disclosure of nonfinancial material sustainability information

A scoring index based on GRI G4 standard disclosures and performance indicators (Table 1) has been developed to compute non-financial material sustainability scores for specific performance indicators following the disclosurescoring methodology of Al-Tuwaijri et al., (2004). Following their disclosure-scoring methodology, the study denotes ' 1 ' for the presence of each performance indicator and ' 0 ' for the absence of any performance indicator of the GRI G4 guidelines. This gives a company score for each of the economic, environmental and social aspects. Then a measure of aggregate sustainability score for each of the aspects for every company is constructed. After combining all three aspects (economic, environmental and social) the study determines the "aggregate non-financial material sustainability score" for every company.

Table 1: Summary of GRI G4 standard disclosures and performance indicators

\begin{tabular}{|c|c|c|c|}
\hline Disclosure Category & Aspects & $\begin{array}{l}\text { Category } \\
\text { of score }\end{array}$ & $\begin{array}{c}\text { Total Disclosures } \\
\text { and score }\end{array}$ \\
\hline \multirow{8}{*}{$\begin{array}{l}\text { Standard disclosures: } \\
\text { Performance indicators }\end{array}$} & 1. Economic (G4-EC 1 to EC 9) & & 9 \\
\hline & 2. Environmental (G4-EN 1 to EN 34) & & 34 \\
\hline & 3. Social & & \\
\hline & Social - Labour Practices and Decent Work (G4-LA 1 to LA 16) & 16 & \\
\hline & Social - Human Rights (G4-HR 1 to HR 12) & 12 & \\
\hline & Social - Society (G4-SO 1 to SO 11) & 11 & \\
\hline & Social - Product Responsibility (G4-PR 1 to PR 9) & 9 & 48 \\
\hline & \multicolumn{2}{|c|}{ Aggregate material sustainability score } & 91 \\
\hline
\end{tabular}

Source: Global Reporting Initiative. (2013b, pp.19-22).

Note: The presence of each indicator is scored 1 and absence is scored 0.

\section{Reliability of scoring index and its validation}

To ensure the accuracy, consistency and reliability of the ratings derived by us, the validation of the scoring index was done. Different studies (Khan et al., 2016; Ong, 2016; Ong et al., 2016; Hummel and Schlick, 2016; Al-Tuwaijri et al., 2004) used raters or coders when there is a requirement for such validation. In this context, Gwet (2008, p. 29) states, "Inter-rater reliability quantifies the closeness of scores assigned by a pool of raters to the same study participants. The closer the scores, the higher the reliability of the data collection method". The study uses two external validators, who are familiar with the GRI G4 guidelines so that they can independently map the GRI G4 scoring index to validate the non-financial material sustainability disclosure score measured by us. The two most common measures used to assess the reliability among validators in the literature are percent agreement and Cohen's kappa (McHugh, 2012). This study uses percent agreement measure (McHugh, 2012) to determine the degree of agreement among the raters' scores. There is a high percentage agreement among the raters, $83.33 \%$ to $100 \%$, which is in excess of the widely agreed acceptable interrater limit of $80 \%$ (McHugh, 2012).

\section{Empirical models and estimations: Ordinary least squares (OLS) and fixed-effects}

To analyse the relationship between companies' disclosure of material sustainability information and their financial performance, this study uses two estimation approaches: ordinary least squares (OLS) and fixed-effects regression analysis. 
Two elements of the empirical analysis in the present study of the relationship between disclosure of non-financial material sustainability information and company financial performance are noteworthy. First, the study uses a oneyear lagged value of disclosure score for non-financial material sustainability information, which avoids the possibility of reverse causality since the current year's financial performance could not have affected the score for disclosure of material information in the past. Second, the study uses fixed-effects regression analysis (Wooldridge, 2010), which allows accounting for all firm characteristics that are fixed over time, and thereby reduce the chances of bias in the estimated effects from an inability to control for other unobserved factors that may influence both companies' disclosure score and their financial performance.

As companies may self-select into the extent to which they disclose material sustainability information, systematic underlying differences may exist between the companies who score well in the disclosure of material information versus those that don't. These differences might be reflected in company characteristics that can be readily captured by their past financial performance as well as characteristics that are difficult to measure (e.g., the company management team's outlook about and commitment to sustainability issues). Because these characteristics may influence current financial performance as well as the extent of disclosure of material sustainability information, failure to account for them in the regression analysis would be tantamount to omitting relevant control variables from the model. Consequently, this would result in a biased estimate of $\alpha_{1}$ in Equation 1 (or $\alpha_{1}, \alpha_{2}$ and $\alpha_{3}$ in Equation 2). More specifically, if there are unobserved differences that are correlated with both material information disclosure score and company financial performance, then estimating Equations 1 and 2 using the OLS regression method would produce a biased estimate of the relationship of disclosure score on financial performance (Hasan et al., 2016). If these unobserved firm characteristics is denoted by $c_{i}$, then the true relationship of interest from equation (1) is given by FinPerfit $=\alpha_{0}+\alpha_{1}$ Aggregate material sustainability score $\mathrm{i}_{(\mathrm{t}-1)}+\alpha_{2} \mathrm{X}_{\mathrm{i}(\mathrm{t}-1)}+\alpha 3$ $\mathrm{Z}(\mathrm{it})+\mathrm{Ci}+\mathrm{e}_{\mathrm{it}}$. If $c_{i}$ is correlated with both "aggregate material sustainability score i(t-1)" $^{\prime}$ and "FinPerfit", then an OLS estimate of $\alpha_{1}$ that does not account for that correlation will be biased.

The present study first uses OLS estimation approach as a starting point for the regression results. As noted above, the present study also applies the fixed-effects estimation approach to obtain a less biased estimate, as the OLS results are potentially biased (Wooldridge, 2010). Different studies (e.g., Atan et al., 2018; Khan et al., 2016; Hasan et al., 2016) also use fixed-effects estimates in exploring the relationship between non-financial sustainability information and companies' financial performance. The control variables that are fixed over time drop out of the fixed-effects estimation of Equations 1, and 2, due to differences. This approach is expected to reduce (if not eliminate) bias in estimated $\alpha_{1}$ relative to the OLS estimates, under the assumption that there are no timevarying firm characteristics that are correlated with their current financial performance.

Although in our analysis we estimated OLS regressions to compare the results from the firm-level fixed-effects analysis, we focus on the findings from the fixed-effects analysis and consider these as the main findings of the study.

\section{Empirical models and estimations for all companies}

This study first estimates an equation of the following form for aggregate non-financial material sustainability information for all companies.

\section{Equation 1}

FinPerf $f_{i t}=\alpha_{0}+\alpha_{1}$ Aggregate material sustainability score $i(t-1)+$ $\alpha_{2} X_{i(t-1)}+\alpha 3 Z_{(i t)+e_{i t}}$

where $\alpha_{0}$ is a constant and $\alpha_{1}$ is the coefficient of interest. $\mathbf{e}_{i t}$ signifies the error term. The variables in Equation 1 are described below.

\section{Dependent variable: 'FinPerfit'}

The dependent variable of the regression is 'FinPerfit'. 'FinPerfit' is the financial performance of a company (i), in the year ( $t$ ) as measured by return on asset (ROA), return on equity (ROE) and Tobin's $Q$. We use both accountingbased (ROA, ROE) and market-based (Tobin's Q) measures of company financial performance as a dependent (outcome) variable. Both measures are extensively accepted and used as a valid indicator for analyzing the financial performance of a company (Gentry and Shen, 2010). A number of studies (Khan et al., 2016; Kang et al., 2016; Petrenko et al., 2016; Flammer, 2015; Choi et al., 2010) use a combination of both the measures to examine the financial performance of the companies.

Return on assets (ROA) measures the efficiency of a company in generating profit from its assets, irrespective of the company size. ROA is calculated in this study as the ratio between net income and total assets (net income / total asset). A number of prior studies related to nonfinancial sustainability disclosure also use ROA to measure the financial performance of companies (Khan et al., 2016; Kang et al., 2016; Petrenko et al., 2016; Waddock and Graves, 1997).

The return on equity (ROE) is used to assess how a company excellently uses its shareholders' or investors' capital (equity). ROE is measured as the ratio between net income and total equity (net income / total equity) in this study. Prior studies related to companies' sustainability disclosure also use $\mathrm{ROE}$ in measuring the financial performance of companies (Flammer, 2015; Saeidi et al., 2015; Chetty et al., 2015; Waddock and Graves, 1997). 
We use Tobin's Q as a market-based financial performance. The market-based measures show the long-term expectations of shareholders or investors regarding the company's future financial performance (earning) on the basis of the company's present or previous financial performance (Hasan et al., 2016; Miller, 2004; Shah and Hussain, 2012; Shan and McIver, 2011; Ganguli and Agrawal, 2009). In general, higher valued companies will have higher Tobin's compared with lower valued companies. Following Hasan et al., (2016), Tobin's Q in this study is measured by the market value of a company in relation to the book value of a company's total assets (Book value of total assets - book value of equity + market value of equity / Book value of total assets).

The principal independent variable of interest: Aggregate material sustainability score $i(t-1)$

Aggregate material sustainability score $_{i(t-1)}$ is the principal variable of interest in this study based on the scoring index developed in Section 3.4. The study estimates the influence of a one-year lagged value of aggregate material sustainability score on financial performance.

Control variables: $X_{i(t-1)}$ and $Z_{(i t)}$

$X_{i(t-1)}$ and $Z_{(i t)}$ signifies a variety of control variables that are included in the model. $\boldsymbol{X}_{i(t-1)}$ includes the company's financial performance in the preceding year $(t-1)$, i.e. oneyear lagged value of the company's financial performance (ROA, ROE and Tobin's Q).

$\boldsymbol{Z}_{\text {(it) }}$ includes company size, company age, leverage, principal activities of the company and sectoral economic condition (rates of growth of the mining industry as a proxy) in the year (t). These control variables are discussed below.

Company size: In the current study, company size is measured as the calendar year-end market capitalization in the year ( $t$ ). For example, Khan et al., (2016) measures company size based on market capitalization.

Company age: In this study, we calculate company age on the basis of the number of years since its listing in the ASX in year t. Company age can be calculated based on the number of years since the firm's inception (Saeidi et al., 2015; Gelhard and Von Delft, 2016) as well as based on the number of years since its listing in the stock exchange (Dissanayake et al., 2016).

Leverage: This study uses a leverage ratio to assess companies' debt levels in year $t$. It is calculated here by dividing total debt (Long term debt plus current debt) by total assets (total debt / total asset) at year-end. Some prior studies also use leverage ratio as a control variable (Gao et al., 2016; Kang et al., 2016; Khan et al., 2016; Clarkson et al., 2008).

Principal activities of the company: The study classifies the principal activities of the sample companies into three broad categories based on the ASX classification of the companies' principal activities. They are mining and metals exploration and development, mineral explorations, and others. These three activities are controlled in the year $(\mathrm{t})$.

Sectoral economic condition: Rate of growth in the mining industry in the year $(\mathrm{t})$ is used as a proxy for growth in the materials sector since the mining industry is a substantial component of the materials sector. The nominal growth rate of the Australian mining industry was 7.7 percent in 2015 and 6.2 percent in 2016 (Based on Australian Bureau of Statistics (ABS), 2017)).

To understand the relationship of the three aspects of sustainability disclosure identified in the GRI G4 guidelines-namely, economic, environmental and social aspects-this study also estimates the following variant (Equation 2) of Equation 1.

\section{Equation 2}

FinPerf $_{i t}=\alpha_{0}+\alpha_{1}$ Economic material sustainability score E $(t-1)+\alpha_{2}$ Environmental material sustainability score $e_{i(t-1)}+\alpha_{3}$ Social material sustainability score $e_{(t-1)}+\alpha_{4} X_{i(t-1)}+\alpha 5 Z_{(i t)}+e_{i t}$

In Equation 2, this study replaces the aggregate sustainability score in Equation 1 with separate scores for each of the three (economic, environmental and social) aspects of sustainability disclosure. Consequently, $\alpha_{1}, \alpha_{2}$ and $\alpha_{3}$ are the coefficients of interest. Economic material sustainability score $(\mathrm{t} t-1)$, environmental material

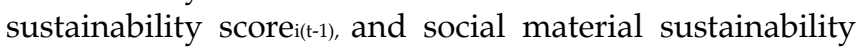
score $_{i(t-1)}$ are the principal variables of interest. All other variables and parameters are as defined for Equation 1. Estimation of Equation 2 would allow to separately assess the influence of disclosure of economic, environmental and social sustainability information on company financial performance while controlling for other company characteristics.

Ordinary least squares (OLS) regression and fixed-effects regression with robust standard error estimation methods are used to estimate Equations 1 and 2.

\section{FINDINGS AND DISCUSSION}

This section discusses the study finding for all companies. The results of the OLS and fixed-effects estimates for all companies are shown respectively in Appendix A (Tables A I through AII). The descriptive statistics for all variables of Equations 1, and 2, are presented in the Appendix B.

Table A I (Appendix A) present the findings from the OLS and fixed-effects regression analysis, which examines the relationship between lagged aggregate disclosure of nonfinancial material sustainability information and financial performance for all companies in the sample. Based on the Equation 1, the OLS regression results in Table Table A1 (Appendix A) suggest that the lagged aggregate material sustainability score does not have any statistically significant relationship with accounting-based financial measures (ROA ROE) and market-based financial measure (Tobin's Q). 
After accounting for time-invariant unobserved variables, based on the Equation 1, the fixed-effects regression results in Table A1 (Appendix A) show a mixed relationship (no relationship and statistically significant negative relationship) between lagged aggregate material sustainability score and companies' financial performances as measured by ROA, ROE and Tobin's Q. The lagged aggregate material sustainability score does not have any significant relationship with accounting-based financial measures (ROA and ROE). However, the lagged aggregate material sustainability score has a statistically significant negative relationship with the market-based financial measure (Tobin's Q) at the 5 percent level of significance. Specifically, this implies that a unit change in a company's aggregate material score in the preceding year is associated with a decrease in Tobin's $Q$ in the current year by 11 percent.

Although in theory the relationship between lagged aggregate material sustainability score and Tobin's Q could be either positive or negative (Gao and Bansal, 2013). Investors are sensitive to the desirable sustainability information (Alexander and Buchholz, 1978; Van Dijken, 2007; Lins et al., 2017) and CSR does not influence company performance in the short run but has some positive effect in the long term (McWilliam and Siegel, 2000; and Lin et al., 2009). When investors find the CSR disclosure as credible, informative and meeting their expectations, there should be a positive relationship between the CSR disclosure and companies' financial performance; otherwise, the relationship could be unrelated or negatively related. If companies' disclosure of non-financial sustainability issues does not meet the market (investor) expectations, it may lead to the downward revision of market (investors) expectations of future cash flows, resulting in a decreased Tobin's Q (Cahan et al., 2016). A higher lagged aggregate material sustainability score may imply a higher level of investment in environmental and social projects. Such an investment may not yield the expected outcome in the short run, and consequently, investors could view this as unnecessary use of resources (given opportunity cost). This may weaken their confidence level. As a result, the market value of the company may fall (while book value remains unchanged), resulting in a lower Tobin's $Q$ ratio.

One of the plausible reasons for having no relationship or negative relationship between non-financial material sustainability disclosure and financial performance may be due to the short time-frame of the present study. As the study period for the analysis in the present study is twoyears, it may have influenced the study results. Garg (2015) show that companies' sustainability reporting practices negatively impact on their financial performance in the short run while it positively influences in the long run. The earlier study by Lin et al., (2009) also shows that CSR may not have a positive influence on companies' financial performance in the short run but it has a notable positive influence in the long run.
Further, the link between the companies' disclosure of non-financial material sustainability information and their financial performance in this study stems from the companies' stakeholder pressure, legitimacy pressure and analysis of the costs of investing in economic, environmental and social sustainability issues. The findings of the present study which shows no statistically significant relationship or statistically negative significant relationship between the lagged non-financial material sustainability disclosure and financial performance, may suggest that the costs of investing in sustainability issues play a role in determining the relationship. The companies may provide voluntary disclosures when they think the benefits of disclosure exceed the cost of the companies' involvement in environmental and social activities, as the sustainability disclosures are potentially costly (e.g., Verrecchia, 1983; Cormier and Gordon, 2001; Elijido-Ten, 2007). Non-financial sustainability disclosure may not portray the true picture of the companies' sustainability practices and sustainability performance that gives an effect to companies' financial performance, as sustainability reporting is predominantly voluntary in Australia. Moreover, managers' opportunistic behaviour also has an influence on companies' voluntary disclosure of the non-financial sustainability issues (Verrecchia, 1990) regarding what is or is not disclosed.

The companies in this study sample may report their nonfinancial sustainability information to: 1) increase companies' transparency; 2) enhance brand value, reputation and legitimacy; 3) enable benchmarking against competitors; 4) signal competitiveness; 5) motivate employees and support corporate information; and 6) control processes through disclosing sustainability information (Herzig and Schaltegger, 2006) without relating their disclosure of non-financial material sustainability information with the companies' financial performance. may be due to information asymmetry between the market (that is, the investors) and company managers (Alexander and Buchholz, 1978; Van Dijken, 2007; Lins et al., 2016).

Based on the Equation 2, while exploring the separate relationship between the lagged economic, environmental and social non-financial material sustainability disclosure and financial performance, the OLS regression results shown in Table A2 (Appendix A), do not show statistically significant relationship between the lagged economic material sustainability score and the companies' financial performance. Further, the OLS results show mixed results (negative, positive and no relationship) between the lagged environmental and social material sustainability score and companies' financial performance. However, after accounting for time-invariant unobserved variables, based on the Equation 2, the fixed-effects regression results, shown in Table A2 (Appendix A), show no statistically significant relationship between the lagged economic, environmental and social disclosure of nonfinancial material sustainability information and 
companies' financial performance for all companies. It suggests that a change in the lagged economic, environmental and social material sustainability score in the previous year does not have any statistically significant implications on the financial performance of the company in the current year.

\section{CONTRIBUTION AND IMPLICATIONS}

The present study contributes to the existing literature on disclosure of non-financial sustainability information by adding insights into the materiality concept of nonfinancial sustainability disclosure in the Australian context. This study contributes to the existing non-financial material sustainability disclosure literature in terms of: (1) developing a scoring index; (2) applying a stronger methodological approach than what has been applied in the related research literature (Ong et al. 2016; Ong, 2016) in the Australian context; (3) using a one-year lagged value of disclosure scores, which avoids the possibility of reverse causality; (4) concurrently examining three aspects of material sustainability information: economic, environmental and social, while exploring the relationship between companies' disclosure of non-financial material sustainability information and their financial performance; (5) generating new empirical evidence on this issue for Australian companies in a specific sector, namely, the materials sector.

The evidence from the current study is expected to provide useful information for the companies' stakeholders in Australia who use both financial and non-financial information for formulating business and regulatory policies and for making decisions. As the present study portrays the sector-specific (materials sector) analysis of the non-financial disclosure of sustainability information, this may also be beneficial for diverse stakeholders in this sector. As a company's sustainability is related to its economic viability as well as social and environmental responsibility (AICPA, 2013), the disclosure of nonfinancial sustainability information may reflect the company being focused on business that targets long-term value creation. There is a worldwide increase in awareness about sustainability reporting practices among different policymakers as well as regulators (Platonova et al., 2018). In this regard, the Australian companies in the material sector, as well as in other sectors, may continue to increase their non-financial material sustainability information, which includes disclosure of economic, environmental and social information relevant for a large segment of the Australian economy.

It is worth reiterating that different stakeholders have different needs and demands for the disclosure of nonfinancial sustainability information. As stakeholder resources are critical to the achievement and viability of an organization (Ullmann, 1985), companies are likely to satisfy the stakeholder demands. For example, company shareholders are interested in making informed decision regarding their investments, and the present study's finding about the increased disclosure over time of material sustainability information may build a positive image among the shareholders. The study results are also relevant for the creditors, because they may be interested to give credit to those companies that disclose more on sustainability information. Employees, suppliers, and consumers may also form a positive view of the companies that disclose more material sustainability information over time. The media and other interest groups such as, environmental activists and the general public may also be interested in the social, economic, and environmental sustainability aspects of a company, and would likely appreciate companies that report on these different aspects of sustainability. Increase in disclosure of non-financial materials sustainability information over time by the sampled ASX companies in the material sector may therefore reflect the companies' attention to meeting the diverse stakeholder interests in this regard.

\section{LIMITATIONS}

As with most studies, the present study has some limitations. Therefore, the empirical results of this study should be interpreted cautiously and carefully. The primary limitation of this study is that the findings may not generalize to Australian listed companies across all sectors, or to non-listed companies because the study findings are based on data from the Australian listed companies in the materials sector. As the data on disclosure of material sustainability information for the present study were manually collected by the researchers through content analysis of various reports published by the companies, it was not possible to extend the sample size beyond 100 companies due to resource and time constraints. Moreover, this study does not measure the substance or extent of disclosure when assessing non-financial material sustainability disclosure; instead, it focuses on whether or not certain indicators in the GRI G4 guidelines are publicly reported.

The fixed-effects estimation used in the present study cannot completely rule out the potential for other timevarying factors confounding the estimates. This is a general limitation of the fixed-effect estimation approach. Although fixed-effect estimation is expected to reduce bias compared to simple OLS estimation, it does not account for the unobserved time-varying factors (Wooldridge, 2010). Consequently, the present study cannot apply causal attribution in the link between non-financial material sustainability score and company financial performance.

\section{FutuRE RESEARCH}

Based on the present study findings, there are a few suggestions for future research. It would be interesting to apply the newly developed GRI G4 based non-financial materiality disclosure index to companies in other sectors. Subsequent research may expand the analysis to ASX 
listed companies in other sectors and produce evidence that would be generalizable across sectors. Again, future research may compare the results between developing and developed country context to explore whether the findings vary based on the country context. Future research may also look to explore ways to identify the causal link between non-financial material sustainability score and company financial performance. Moreover, future research may conduct case studies with individual companies to gain deeper insights about the relationship between non-financial material sustainability disclosure and company financial performance.

\section{CONCLUSION}

Findings from this study add insights into the materiality concept of non-financial sustainability disclosure in the Australian context. This study may be useful for corporate leaders, investors, shareholders, company managers and other policymakers in Australia, who use both financial and non-financial information for formulating business policies and making decisions. As the concept of disclosure of non-financial material sustainability information is gaining momentum, continued future research in this field may unfold additional avenues for the Australian companies as well as in the other countries.

\section{REFERENCES}

Abbott, W.F. and Monsen, R.J., 1979. On the measurement of corporate social responsibility: Self-reported disclosures as a method of measuring corporate social involvement. Academy of Management Journal,22(3), pp.501-515.

Alexander, G.J. and Buchholz, R.A., 1978. Corporate social responsibility and stock market performance. Academy of Management Journal, 21(3), pp.479-486.

Al-Tuwaijri, S.A., Christensen, T.E. and Hughes Ii, K.E., 2004. The relations among environmental disclosure, environmental performance, and economic performance: a simultaneous equations approach. Accounting, Organizations and Society, 29(5-6), pp.447-471.

Amel-Zadeh, A., 2016. The materiality of nonfinancial information: a review of theory and empirical evidence on sustainability disclosures, corporate social responsibility and responsible investing. Available at: https:/ / papers.ssrn.com/sol3/papers.cfm?abstract_id $=2664547$

Andrikopoulos, A. and Kriklani, N., 2013. Environmental disclosure and financial characteristics of the firm: The case of Denmark. Corporate Social Responsibility and Environmental Management, 20(1), pp.55-64.

Atan, R., Alam, M.M., Said, J. and Zamri, M., 2018. The impacts of environmental, social, and governance factors on firm performance. Management of Environmental Quality: An International Journal, 29(2), pp.182-194.
Australian Bureau of Statistics (ABS), 2015. Australian National Accounts: National Income, Expenditure and Product, 5206.0. Available at: http:/ /www.abs.gov.au/AUSSTATS/abs@.nsf/Detail sPage/5206.0Dec\%202015?OpenDocument

Australian Bureau of Statistics (ABS), 2017. Australian National Accounts: National Income, Expenditure and Product, 5206.0. Available at: https:/ /www.abs.gov.au/AUSSTATS/abs@.nsf/Deta ilsPage/5206.0Dec\%202017?OpenDocument

Ball, A., Broadbent, J. and Jarvis, T., 2006. Waste management, the challenges of the PFI and 'sustainability reporting'. Business Strategy and the Environment, 15(4), pp.258-274.

Bowerman, B.L., O'Connell, R.T. and Murphree, E.S., 2019. Business Statistics in Practice: Using Data, Modeling, and Analysis. $8^{\text {th }}$ edition. McGraw-Hill.

Brown, H.S., de Jong, M. and Levy, D.L., 2009. Building institutions based on information disclosure: lessons from GRI's sustainability reporting. Journal of Cleaner Production, 17(6), pp.571-580.

Cahan, S.F., De Villiers, C., Jeter, D.C., Naiker, V. and Van Staden, C.J., 2016. Are CSR disclosures value relevant? Cross-country evidence. European Accounting Review, 25(3), pp.579-611.

Callan, S.J. and Thomas, J.M., 2009. Corporate financial performance and corporate social performance: an update and reinvestigation. Corporate Social Responsibility and Environmental Management, 16(2), pp.61-78.

Chen, K.H. and Metcalf, R.W., 1980. The relationship between pollution control record and financial indicators revisited. The Accounting Review, 55(1), pp.168-177.

Chetty, S., Naidoo, R. and Seetharam, Y., 2015. The impact of corporate social responsibility on firms' financial performance in South Africa. Contemporary Economics, 9(2), pp.193-214.

Choi, H. and Moon, D., 2016. Perceptions of corporate social responsibility in the capital market. Journal of Applied Business Research (JABR), 32(5), pp.1507-1518.

Choi, J.S., Kwak, Y.M. and Choe, C., 2010. Corporate social responsibility and corporate financial performance: Evidence from Korea. Australian Journal of Management, 35(3), pp.291-311.

Clarkson, P.M., Li, Y., Richardson, G.D. and Vasvari, F.P., 2008. Revisiting the relation between environmental performance and environmental disclosure: An empirical analysis. Accounting, Organizations and Society, 33(4-5), pp.303-327.

Cochran, P.L. and Wood, R.A., 1984. Corporate social responsibility and financial performance. Academy of Management Journal, 27(1), pp.42-56. 
Cormier, D. and Gordon, I.M., 2001. An examination of social and environmental reporting strategies. Accounting, Auditing \& Accountability Journal, 14(5), pp.587-617.

Dissanayake, D., Tilt, C. and Xydias-Lobo, M., 2016. Sustainability reporting by publicly listed companies in Sri Lanka. Journal of Cleaner Production, 129, pp.169-182.

Dong, S. and Burritt, R., 2010. Cross-sectional benchmarking of social and environmental reporting practice in the Australian oil and gas industry. Sustainable Development, 18(2), pp.108-118.

Eccles, R.G., Krzus, M.P., Rogers, J. and Serafeim, G., 2012. The need for sector-specific materiality and sustainability reporting standards. Journal of Applied Corporate Finance, 24(2), pp.65-71.

Edgley, C., Jones, M.J. and Atkins, J., 2015. The adoption of the materiality concept in social and environmental reporting assurance: A field study approach. The British Accounting Review, 47(1), pp.1-18.

Elijido-Ten, E., 2007. Applying stakeholder theory to analyze corporate environmental performance. Asian Review of Accounting, 15(2), pp.164-184.

Flammer, C., 2013. Corporate social responsibility and shareholder reaction: The environmental awareness of investors. Academy of Management Journal,56(3), pp.758-781.

Flammer, C., 2015. Does corporate social responsibility lead to superior financial performance? A regression discontinuity approach. Management Science, 61(11), pp.2549-2568.

Font, X., Guix, M. and Bonilla-Priego, M.J., 2016. Corporate social responsibility in cruising: Using materiality analysis to create shared value. Tourism Management, 53, pp.175-186.

Frost, G., Jones, S., Loftus, J. and Van Der Laan, S., 2005. A survey of sustainability reporting practices of Australian reporting entities. Australian Accounting Review, 15(35), pp.89-96.

Ganguli, S.K. and Agrawal, S., 2009. Ownership Structure and Firm Performance: An Empirical Study on Listed Mid-Cap Indian Companies. IUP Journal of Applied Finance, 15(12).

Gao, F., Dong, Y., Ni, C. and Fu, R., 2016. Determinants and economic consequences of non-financial disclosure quality. European Accounting Review, 25(2), pp.287-317.

Gao, J. and Bansal, P., 2013. Instrumental and integrative logics in business sustainability. Journal of Business Ethics, 112(2), pp.241-255.

Garg, P., 2015. Impact of sustainability reporting on firm performance of companies in India. International Journal of Marketing and Business Communication, 4(3), pp.38-45.

Gelhard, C. and Von Delft, S., 2016. The role of organizational capabilities in achieving superior sustainability performance. Journal of Business Research, 69(10), pp.4632-4642.

Gentry, R.J. and Shen, W., 2010. The relationship between accounting and market measures of firm financial performance: How strong is it?. Journal of Managerial Issues, 22(4), pp.514-530.

Global Reporting Initiative (GRI), 2013a. GRI G4 reporting principles and standard disclosures. Available at: https://www.globalreporting.org/resourcelibrary/G RIG4-Part1-Reporting-Principles-and-StandardDisclosures.pdf

Global Reporting Initiative (GRI), 2013b. GRI G4 implementation manual. Available at: https://www.globalreporting.org/resourcelibrary/G RIG4-Part2-Implementation-Manual.pdf

Griffin, J.J. and Mahon, J.F., 1997. The corporate social performance and corporate financial performance debate: Twenty-five years of incomparable research. Business \& Society, 36(1), pp.5-31.

Guthrie, J. and Abeysekera, I., 2006. Content analysis of social, environmental reporting: what is new? Journal of Human Resource Costing \& Accounting, 10(2), pp.114-126.

Guthrie, J. and Parker, L., 1990. Corporate social disclosure practice: a comparative international analysis. Advances in Public Interest Accounting, 3, pp.159-175.

Gwet, K.L., 2008. Computing inter-rater reliability and its variance in the presence of high agreement. British Journal of Mathematical and Statistical Psychology, 61(1), pp.29-48.

Hasan, I., Kobeissi, N., Liu, L. and Wang, H., 2018. Corporate social responsibility and firm financial performance: The mediating role of productivity. Journal of Business Ethics, 149(3), pp.671688.

Herzig, C. and Schaltegger, S., 2006. Corporate sustainability reporting. An overview. In Schaltegger, S., Bennett, M., Burritt, R.L. (Eds.), Sustainability accounting and reporting (pp. 301-324). Springer, Dordrecht.

Higgins, C., Milne, M.J. and Van Gramberg, B., 2015. The uptake of sustainability reporting in Australia. Journal of Business Ethics, 129(2), pp.445-468.

Hummel, K. and Schlick, C., 2016. The relationship between sustainability performance and sustainability disclosure-Reconciling voluntary disclosure theory and legitimacy theory. Journal of Accounting and Public Policy, 35(5), pp.455-476.

Jones, P., Comfort, D. and Hillier, D., 2016. Materiality in corporate sustainability reporting within UK retailing. Journal of Public Affairs, 16(1), pp.81-90.

Jones, S., Frost, G., Loftus, J. and van der Laan, S., 2007. An empirical examination of the market returns and financial performance of entities engaged in 
sustainability reporting. Australian Accounting Review, 17(41), pp.78-87.

Kang, C., Germann, F. and Grewal, R., 2016. Washing away your sins? Corporate social responsibility, corporate social irresponsibility, and firm performance. Journal of Marketing, 80(2), pp.59-79.

Khan, M., Serafeim, G. and Yoon, A., 2016. Corporate sustainability: First evidence on materiality. The Accounting Review, 91(6), pp.1697-1724.

KPMG \& SustainAbility., 2008. Count me in: the reader's take on sustainability reporting. Available at https://www.globalreporting.org/resourcelibrary/C ount-Me-In-The-Readers-take-on-SustainabilityReporting.pdf

KPMG International Cooperative. 2015. Currents of change: The KPMG survey of corporate responsibility reporting. Netherlands: KPMG.

Kyte, R., 2007. Balancing rights with responsibilities: looking for the global drivers of materiality in corporate social responsibility \& (and) the voluntary initiatives that develop and support them. American University International Law Review., 23, p.559.

Lin, C.H., Yang, H.L. and Liou, D.Y., 2009. The impact of corporate social responsibility on financial performance: Evidence from business in Taiwan. Technology in Society, 31(1), pp.56-63.

Lins, K.V., Servaes, H. and Tamayo, A., 2017. Social capital, trust, and firm performance: The value of corporate social responsibility during the financial crisis. The Journal of Finance, 72(4), pp.1785-1824.

Lu, W. and Taylor, M.E., 2016. Which factors moderate the relationship between sustainability performance and financial performance? A meta-analysis study. Journal of International Accounting Research, 15(1), pp.1-15.

Lu, W., Chau, K.W., Wang, H. and Pan, W., 2014. A decade's debate on the nexus between corporate social and corporate financial performance: a critical review of empirical studies 2002-2011. Journal of Cleaner Production, 79, pp.195-206.

McHugh, M.L., 2012. Interrater reliability: the kappa statistic. California Biochemia medica: Biochemia medica, 22(3), pp.276-282.

McWilliams, A. and Siegel, D., 2000. Corporate social responsibility and financial performance: correlation or misspecification? Strategic Management Journal, 21(5), pp.603-609.

Miller, D.J., 2004. Firms' technological resources and the performance effects of diversification: a longitudinal study. Strategic Management Journal,25(11), pp.10971119.

Moskowitz, M., 1972. Choosing socially responsible stocks. Business and Society Review, 1(1), pp.71-75.
Ong, S.H., 2016. Measuring the quality and identifying influencing factors of sustainability reporting: Evidence from the resources industry in Australia. Doctor of Philosophy Thesis, Edith Cowan University. Retrieved from http:/ / ro.ecu.edu.au/theses/1922

Ong, T., Trireksani, T. and Djajadikerta, H.G., 2016. Hard and soft sustainability disclosures: Australia's resources industry. Accounting Research Journal, 29(2), pp.198-217.

Petrenko, O.V., Aime, F., Ridge, J. and Hill, A., 2016. Corporate social responsibility or CEO narcissism? CSR motivations and organizational performance. Strategic Management Journal, 37(2), pp.262-279.

Porter, M.E. and Kramer, M.R., 2006. Strategy and society: The link between competitive advantage and corporate social responsibility. Harvard Business Review, 84(12), pp.78-92.

Richards, Z., Thomas, S.L., Randle, M. and Pettigrew, S., 2015. Corporate Social Responsibility programs of Big Food in Australia: a content analysis of industry documents. Australian and New Zealand Journal of Public Health, 39(6), pp.550-556.

Saeidi, S.P., Sofian, S., Saeidi, P., Saeidi, S.P. and Saaeidi, S.A., 2015. How does corporate social responsibility contribute to firm financial performance? The mediating role of competitive advantage, reputation, and customer satisfaction. Journal of Business Research, 68(2), pp.341-350.

Shah, S.Z.A. and Hussain, Z., 2012. Impact of ownership structure on firm performance evidence from nonfinancial listed companies at Karachi Stock Exchange. International Research Journal of Finance and Economics, 84, pp.6-13.

Shan, Y.G. and McIver, R.P., 2011. Corporate governance mechanisms and financial performance in China: Panel data evidence on listed non-financial companies. Asia Pacific Business Review, 17(3), pp.301-324.

Spicer, B.H., 1978a. Investors, corporate social performance and information disclosure: An empirical study. Accounting Review, pp.94-111.

Spicer, B.H., 1978b. Market risk, accounting data and companies' pollution control records. Journal of Business Finance $\mathcal{E}$ Accounting, 5(1), pp.67-83.

Sturdivant, F.D. and Ginter, J.L., 1977. Corporate social responsiveness: Management attitudes and economic performance. California Management Review, 19(3), pp.30-39.

Tilt, C.A., 2001. The content and disclosure of Australian corporate environmental policies. Accounting, Auditing E Accountability Journal, 14(2), pp.190-212.

Ullmann, A.A., 1985. Data in search of a theory: A critical examination of the relationships among social performance, social disclosure, and economic 
performance of US firms. Academy of Management Review, 10(3), pp.540-557.

Unerman, J. and Zappettini, F., 2014. Incorporating materiality considerations into analyses of absence from sustainability reporting. Social and Environmental Accountability Journal, 34(3), pp.172-186.

Van Dijken, F., 2007. Corporate social responsibility: market regulation and the evidence. Managerial Law, 49(4), pp.141-184.

Vance, S.C., 1975. Are socially responsible corporations' good investment risks? Management Review, 64(8), pp.19-24.

Verrecchia, R.E., 1983. Discretionary disclosure. Journal of Accounting and Economics, 5, pp.179-194.
Verrecchia, R.E., 1990. Information quality and discretionary disclosure. Journal of Accounting and Economics, 12(4), pp.365-380.

Waddock, S.A. and Graves, S.B., 1997. The corporate social performance-financial performance link. Strategic Management Journal, 18(4), pp.303-319.

Wooldridge, J., 2010. Econometric analysis of cross section and panel data ( $2^{\text {nd }}$ ed.). Cambridge, MA: MIT Press.

Yongvanich, K. \& Guthrie, J., 2005. Extended performance reporting: An examination of the Australian mining industry. Accounting Forum, 29(1), pp.103-119.

$--0-$

\section{Funding Acknowledgement:}

This study is funded by the "Australian Government Research Training Program (RTP) Scholarship". 


\section{APPENDICES}

\section{Appendix A}

Table A I: OLS and fixed-effects estimates of the relationship between lagged aggregate material sustainability score and financial performance: Analysis for all companies

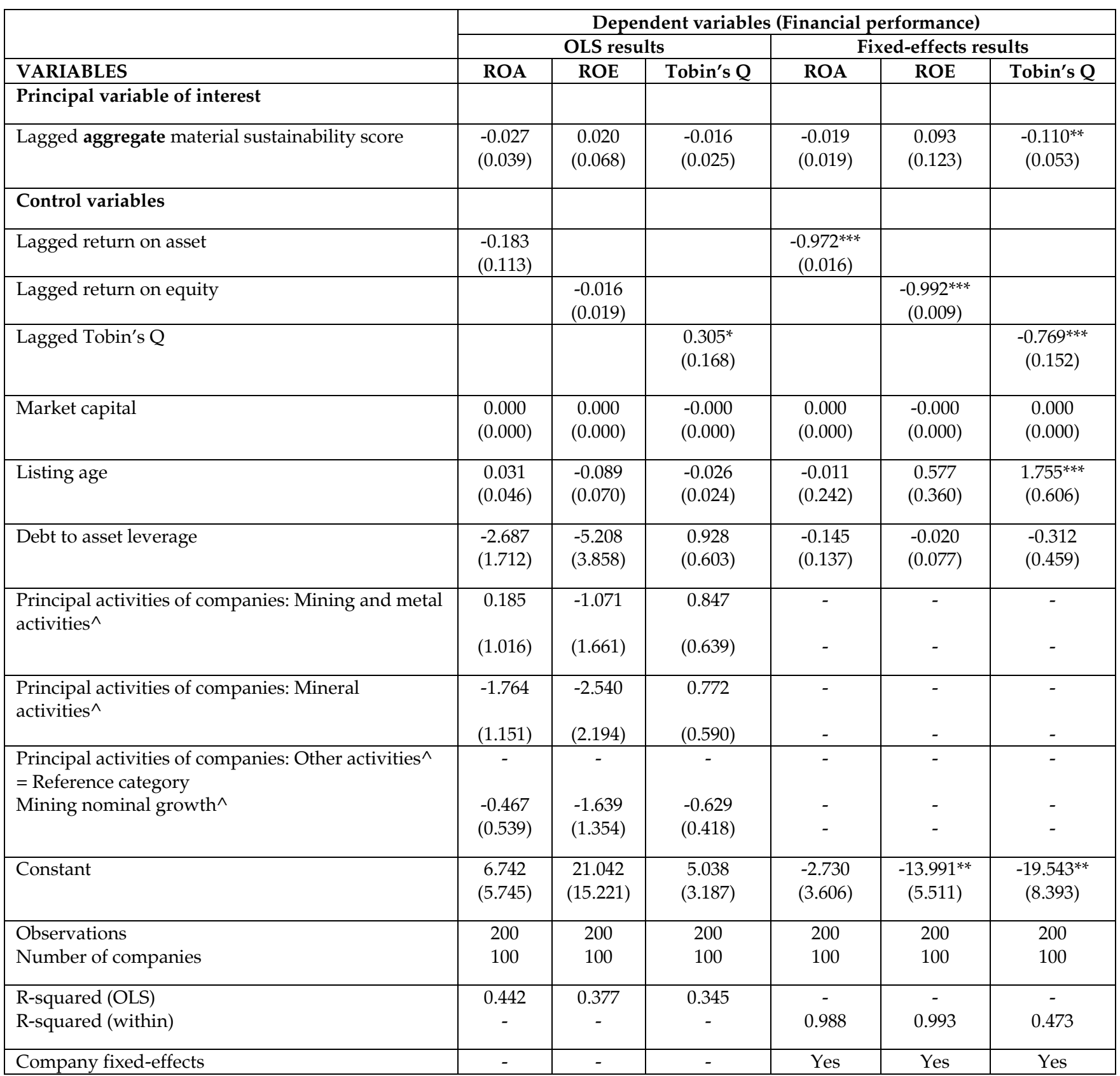

Notes:

1. Regression results are based on Equation 1 shown in the text.

2. Dependent variables shown in the column headings are measures of financial performance.

3. The principal variable of interest is the lagged aggregate material sustainability score.

4. Other activities are the reference category for mining and metal activities and mineral activities.

5. ^ Because this variable is time-invariant, it dropped out of the fixed-effects regression.

6. The first row of each variable shows the coefficient.

7. Robust standard errors are shown in parentheses and *** ${ }^{* *} /{ }^{*}$ suggests that the estimated coefficient is statistically different from zero at the $1 \%, 5 \%$ and $10 \%$ level of significance, respectively. 
Table A II: OLS and Fixed-effects estimates of the relationship between the lagged economic, environmental and social material sustainability score and financial performance: Analysis for all companies

\begin{tabular}{|c|c|c|c|c|c|c|}
\hline \multirow[b]{3}{*}{ VARIABLES } & \multicolumn{6}{|c|}{ Dependent variables (Financial performance) } \\
\hline & \multicolumn{3}{|c|}{ OLS results } & \multicolumn{3}{|c|}{ Fixed-effects results } \\
\hline & ROA & ROE & Tobin's Q & ROA & ROE & Tobin's Q \\
\hline \multicolumn{7}{|l|}{ Principal variable of interest } \\
\hline Lagged economic material sustainability score & $\begin{array}{l}-1.759 \\
(1.275)\end{array}$ & $\begin{array}{l}-0.696 \\
(1.803)\end{array}$ & $\begin{array}{c}0.756 \\
(0.474)\end{array}$ & $\begin{array}{c}0.375 \\
(0.420)\end{array}$ & $\begin{array}{l}-0.624 \\
(1.012)\end{array}$ & $\begin{array}{c}0.752 \\
(1.606)\end{array}$ \\
\hline $\begin{array}{l}\text { Lagged environmental material sustainability } \\
\text { score }\end{array}$ & $\begin{array}{l}-0.321^{*} \\
(0.175)\end{array}$ & $\begin{array}{c}0.446 \\
(0.306)\end{array}$ & $\begin{array}{c}0.080 \\
(0.076)\end{array}$ & $\begin{array}{l}-0.286 \\
(0.184)\end{array}$ & $\begin{array}{c}0.119 \\
(0.353)\end{array}$ & $\begin{array}{l}-0.179 \\
(0.402)\end{array}$ \\
\hline Lagged social material sustainability score & $\begin{array}{l}0.421^{*} \\
(0.227)\end{array}$ & $\begin{array}{l}-0.344 \\
(0.325)\end{array}$ & $\begin{array}{l}-0.180^{* *} \\
(0.090)\end{array}$ & $\begin{array}{c}0.225 \\
(0.157)\end{array}$ & $\begin{array}{c}0.272 \\
(0.219)\end{array}$ & $\begin{array}{l}-0.273 \\
(0.230)\end{array}$ \\
\hline \multicolumn{7}{|l|}{ Control variables } \\
\hline Lagged return on asset & $\begin{array}{l}-0.189 \\
(0.115)\end{array}$ & & & $\begin{array}{c}-0.972^{* * *} \\
(0.016)\end{array}$ & & \\
\hline Lagged return on equity & & $\begin{array}{l}-0.016 \\
(0.019)\end{array}$ & & & $\begin{array}{c}-0.992^{* * *} \\
(0.008)\end{array}$ & \\
\hline Lagged Tobin's Q & & & $\begin{array}{l}0.302^{*} \\
(0.170)\end{array}$ & & & $\begin{array}{c}-0.761^{* * *} \\
(0.141)\end{array}$ \\
\hline Market capital & $\begin{array}{c}0.000 \\
(0.000)\end{array}$ & $\begin{array}{c}0.000 \\
(0.000)\end{array}$ & $\begin{array}{l}-0.000 \\
(0.000)\end{array}$ & $\begin{array}{c}0.000 \\
(0.000)\end{array}$ & $\begin{array}{l}-0.000 \\
(0.000)\end{array}$ & $\begin{array}{c}0.000 \\
(0.000)\end{array}$ \\
\hline Listing age & $\begin{array}{c}0.041 \\
(0.051)\end{array}$ & $\begin{array}{l}-0.078 \\
(0.067)\end{array}$ & $\begin{array}{l}-0.031 \\
(0.025)\end{array}$ & $\begin{array}{l}-0.069 \\
(0.254)\end{array}$ & $\begin{array}{c}0.592 \\
(0.374)\end{array}$ & $\begin{array}{l}1.722^{* * *} \\
(0.580)\end{array}$ \\
\hline Debt to asset leverage & $\begin{array}{l}-2.677 \\
(1.700)\end{array}$ & $\begin{array}{l}-5.222 \\
(3.864)\end{array}$ & $\begin{array}{c}0.923 \\
(0.599)\end{array}$ & $\begin{array}{l}-0.136 \\
(0.129)\end{array}$ & $\begin{array}{l}-0.022 \\
(0.076)\end{array}$ & $\begin{array}{l}-0.299 \\
(0.437)\end{array}$ \\
\hline 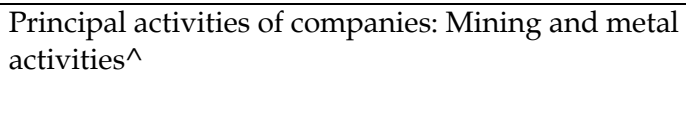 & $\begin{array}{l}-0.304 \\
(1.011)\end{array}$ & $\begin{array}{l}-0.610 \\
(1.527)\end{array}$ & $\begin{array}{c}1.023 \\
(0.648)\end{array}$ & $\begin{array}{l}- \\
-\end{array}$ & $\begin{array}{l}- \\
-\end{array}$ & $\begin{array}{l}- \\
-\end{array}$ \\
\hline 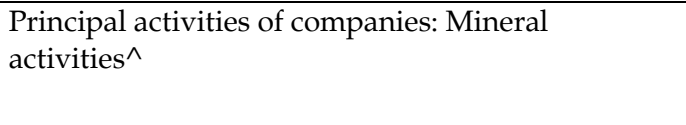 & $\begin{array}{l}-2.029 \\
(1.298)\end{array}$ & $\begin{array}{l}-2.235 \\
(2.190)\end{array}$ & $\begin{array}{c}0.863 \\
(0.620)\end{array}$ & $\begin{array}{l}- \\
-\end{array}$ & $\begin{array}{l}- \\
-\end{array}$ & $\begin{array}{l}- \\
-\end{array}$ \\
\hline $\begin{array}{l}\text { Principal activities of companies: Others activities }{ }^{\wedge} \\
=\text { Reference category }\end{array}$ & - & - & - & - & - & - \\
\hline Mining nominal growth^ & $\begin{array}{l}-0.582 \\
(0.535)\end{array}$ & $\begin{array}{l}-1.703 \\
(1.438)\end{array}$ & $\begin{array}{l}-0.575 \\
(0.413)\end{array}$ & - & - & - \\
\hline Constant & $\begin{array}{c}9.454 \\
(6.274)\end{array}$ & $\begin{array}{c}25.331 \\
(18.764)\end{array}$ & $\begin{array}{c}3.619 \\
(3.212)\end{array}$ & $\begin{array}{l}-4.473 \\
(3.365)\end{array}$ & $\begin{array}{l}-13.716^{* *} \\
(5.411)\end{array}$ & $\begin{array}{l}-20.044^{* *} \\
(9.506)\end{array}$ \\
\hline $\begin{array}{l}\text { Observations } \\
\text { Number of companies }\end{array}$ & $\begin{array}{l}200 \\
100\end{array}$ & $\begin{array}{l}200 \\
100\end{array}$ & $\begin{array}{l}200 \\
100\end{array}$ & $\begin{array}{l}200 \\
100\end{array}$ & $\begin{array}{l}200 \\
100\end{array}$ & $\begin{array}{l}200 \\
100\end{array}$ \\
\hline $\begin{array}{l}\text { R-squared } \\
\text { R-squared (within) }\end{array}$ & $\begin{array}{c}0.452 \\
-\end{array}$ & $\begin{array}{c}0.380 \\
-\end{array}$ & $\begin{array}{c}0.352 \\
-\end{array}$ & $\begin{array}{c}- \\
0.988\end{array}$ & $\begin{array}{c}- \\
0.993\end{array}$ & $\begin{array}{c}- \\
0.476\end{array}$ \\
\hline Company fixed-effects & - & - & - & Yes & Yes & Yes \\
\hline
\end{tabular}

\section{Notes:}

1. Regression results are based on Equation 2 shown in the text

2. Dependent variables shown in the column headings are measures of financial performance.

3. The principal variables of interests are the lagged economic sustainability score, lagged environmental sustainability score and lagged social sustainability score. 
4. Other activities are the reference category for mining and metal activities and mineral activities.

5. ^ Because this variable is time-invariant, it dropped out of the fixed-effects regression.

6. The first row of each variable shows the coefficient.

7. Robust standard errors are shown in parentheses and ${ }^{* * *} / * * /^{*}$ suggests that the estimated coefficient is statistically different from zero at the $1 \%, 5 \%$ and $10 \%$ level of significance, respectively.

Appendix B: Descriptive statistics for all variables of Equations 1, and 2

\begin{tabular}{|c|c|c|c|c|}
\hline VARIABLES & Mean & SD & Min & Max \\
\hline \multicolumn{5}{|l|}{ Financial performances (Dependent variables) } \\
\hline $\mathrm{ROA}$ & -1.67 & 13.32 & -183.60 & 18.97 \\
\hline ROE & -2.38 & 28.59 & -395.86 & 39.18 \\
\hline Tobin's Q & 3.15 & 6.59 & 0.06 & 63.45 \\
\hline \multicolumn{5}{|l|}{ Principal variables of interest } \\
\hline Lagged aggregate material sustainability score & 16.88 & 10.39 & 7 & 59 \\
\hline Lagged economic material sustainability score & 3.01 & 0.69 & 2 & 7 \\
\hline Lagged environmental material sustainability score & 3.71 & 5.40 & 1 & 26 \\
\hline Lagged social material sustainability score & 10.16 & 5.05 & 4 & 32 \\
\hline \multicolumn{5}{|l|}{ Control variables } \\
\hline Lagged return on asset & -1.65 & 13.32 & -183.60 & 18.96 \\
\hline Lagged return on equity & -2.66 & 28.55 & -395.85 & 39.17 \\
\hline Lagged Tobin's Q & 2.15 & 5.10 & 0.04 & 63.45 \\
\hline Market capital (AUD) & $420,339,545$ & $1,859,897,807$ & 1,614 & $17,255,347,500$ \\
\hline Listing age & 15 & 12.56 & 1 & 55 \\
\hline Debt to asset leverage & 1.77 & 2.80 & 0 & 31.90 \\
\hline Principal activities of companies: Mining and metal activities & 0.53 & 0.49 & 0 & 1 \\
\hline Principal activities of companies: Mineral activities & 0.34 & 0.47 & 0 & 1 \\
\hline Principal activities of companies: Other activities & 0.13 & 0.33 & 0 & 1 \\
\hline Mining nominal growth & 7 & 0.75 & 6.20 & 7.70 \\
\hline Observations (N) & \multicolumn{4}{|c|}{200} \\
\hline Number of companies & \multicolumn{4}{|c|}{100} \\
\hline
\end{tabular}

Notes: SD = Standard Deviation; Min = Minimum; Max = Maximum.

\section{How to cite this article}

Mamun, A. A. (2021). Materiality of Disclosure of Non-financial Sustainability Information and Company Financial Performance: Evidence from Australian Listed Companies. American Journal of Trade and Policy, 8(2), 199-214. https://doi.org/10.18034/ajtp.v8i2.565 